\title{
Functional Domains in the Chitin Oligosaccharide Synthase NodC and Related $\beta$-Polysaccharide Synthases
}

\author{
キチンオリゴ糖合成酵素Nod Cと近縁の $\beta$-多糖合成酵素における機能ドメイン
}

\author{
Kamst, Eric ; and Spaink, P. Herman \\ Leiden University, Institute of Molecular Plant Sciences, Wassenaarseweg 64, 2333 AL Leiden, Netherland \\ FAX:31 715275088, E-mail spaink@ rulbim.leidenuniv.nl
}

Key Words : N-acetylglucosamine, nucleotide binding, Rhizobium

\begin{abstract}
Structure-comparisons of glycosyltransferases is hampered by the absence of extended sequence conservations. Only short regions of limited homology have been reported for groups of closely-related transferases such as the $\beta$-galactosyltransferase family, the sialyltransferases, and the $\beta$-polysaccharide synthases: a group of glycosyltransferases involved in the synthesis of linear polysaccharides that consist of $\beta$-linked saccharides. Examples of such enzymes are chitin synthase, cellulose synthase, hyaluronic acid synthase, and the bacterial NodC protein which synthesizes chitin oligosaccharides. In this paper we summarize the known functional aspects of this group of transferases, and possible links with structural aspects. We have found that all members contain six short sequences which are conserved throughout this family. Site-directed mutagenesis studies reported in literature have shown that the conserved residues in these conserved $\beta$-polysaccharide synthase regions are important, or even essential for enzyme activity. Since a detailed study of these mutants with regard to nucleotide-sugar binding or glycosyl acceptor binding has not been reported, the data generated by these studies do not provide information about the precise roles of the conserved $\beta$-polysaccharide synthase regions in substrate-binding and catalysis. However, we report that a novel motif, conserved in all members of this $\beta$-polysaccharide synthase family, is homologous to known nucleotidebinding motifs in nucleoside-triphosphate-binding proteins. In addition we present a sequence analysis that indicates putative functions for the conserved regions in the $\beta$-polysaccharide synthase family in substrate-specificity, catalysis, and product chainlength control.
\end{abstract}

要 約

糖転移酵素の構造の比較は、広い範囲で配列の保存された 領域がないためにあまり進んでいない。互いに近縁な糖転移酵 素である $\beta$-ガラクトシル転移酵素ファミリー、シアル基転移酵 素㧍よび $\beta$ 多糖合成酵素、すなわち $\beta$ 結合多糖からなる直鎖状 の多糖の合成に関与する糖転移酵素のグループについて、狭い 領域における限定されたホモロジーが報告されているのみであ る。そのような酵素の例として、キチン合成酵素、セルロース 合成酵素、ヒアルロン酸合成酵素、そしてキチンオリゴ糖を合 成するバクテリアのNodCタンパクがある。この論文では、これ までに知られているこのグループの転移酵素の機能と構造につ いて整理する。これらすべての酵素は、この糖転移酵素ファミ リーを通じて保存されている6種の短いコンセンサスな配列を 持っている。これまでに報告された部位特異的変異の研究によ り、これらの保存されたアミノ酸残基が酵素活性にとって重要 もしくは必須ですらあることが示されている。ヌクレオチドと 糖の結合、あるいは糖受容体との結合に関連してこれらの配列 に導入された変異の詳細な研究が行われていないため、既存の データからはこのグループの酵素の基質結合性や転移反応にお ける保存領域の正確な役割に関する情報を得ることはできな い。しかしながら、我々はこの $\beta$-多糖合成酵素ファミリーのメ ンバーすべてに保存されている新規のモチーフがヌクレオチド 3リン酸結合タンパクの既知のヌクレオチド結合モチーフと相同 であることを見いだした。また、配列解析の結果に基づいて、 これら $\beta$-多糖合成酵素ファミリーにおける保存領域の基質特異 性、触媒作用および生成糖鎖長の制御における機能についても 議論する。

\section{A. Introduction}

Amino acid sequence conservation in glycosyltransferases is limited to short regions which are only conserved in closely-related enzymes (1-3). The $\beta$-polysaccharide synthase family consists of enzymes that are involved in the synthesis of linear polysaccharides containing $\beta$-linked monosaccharide residues. This family was first recognized when a sequence similar-

\section{A. 序 論}

糖転移酵素で保存されているアミノ酸配列は、近縁の酵素 間においてのみ認められる短い領域に限定されている $(1-3) 。 \beta-$ 多糖合成酵素ファミリーは $\beta$ 結合する単糖残基を含む直鎖状の 多糖の合成に関わる酵素からなる。このファミリーが認知され たのは、細菌のキチンオリゴ糖合成酵素 $(\operatorname{Nod} C)$ といくつかの多 
ity between a bacterial chitin oligosaccharide synthase (NodC) and several polysaccharide synthases was noted. (4-6). The enzymes that are structurally most closely related to NodC are transferases involved in the synthesis of: (i) chitin; the polymer of $\beta 1-4$ linked $N$-acetylglucosamine (GlcNAc) residues which is present in fungal cell-walls and the exoskeletons of crustaceans and insects, (ii) cellulose; the polymer of $\beta 1-4$ linked glucose (Glc) residues present in the cell walls of higher plants and algae and produced by some bacterial species, and (iii) hyaluronic acid (also known as hyaluronan); a co-polymer of GlcNAc and glucuronic acid (GlcA) in [GlcNAc- $\beta 1-4-G l c A-\beta 1-3]$ repeating units which is a constituent of the extracellular matrix in animals, and (iv) chitin oligosaccharides during early development of zebrafish embryos. The polysaccharides chitin and cellulose form the bulk of biopolymers on earth (7), but knowledge about basic aspects of their biosynthesis is marginal. The biosynthesis of chitin oligosaccharides by the rhizobial protein NodC has recently been characterized in vitro, and structurefunction studies on this enzyme are in progress. Three features of NodC make it a useful protein to perform studies on structure-function relationships: (i) the nodC gene has been cloned from several rhizobial strains, (ii) NodC is a non-essential enzyme which allows mutational analysis that are not possible for a number of other members of the $\beta$-polysaccharide synthases, and (iii) its product is an oligosaccharide rather than a polysaccharide which simplifies the characterization of the enzyme-product. Here we discuss a model of chitin oligosaccharide biosynthesis, and a sequence analysis of the $\beta$-polysaccharide synthase family. Six conserved regions are presented, and their possible functions in substrate-binding, catalysis, and control of product chain-length are discussed.

\section{B. Chitin Oigosaccharide Biosynthesis by the Rhizobial Nodulation Protein NodC}

Plants that belong to the Leguminosae family are able to establish a symbiosis with soil bacteria belonging to the genera Rhizobium, Sinorhizobium, Mesorhizobium, Bradyrhizobium and Azorhizobium (collectively called rhizobia). The result of this symbiosis is the formation of a new organ, the root nodule, in which differentiated bacteria convert atmospheric nitrogen into ammonia. In response to flavonoids present in the exudate of host plants, rhizobia secrete metabolites which were initially detected due to their ability to elicit root hair deformation on host plants. These metabolites (named Nod factors) have been purified from a large number of rhizobial strains. Their chemical structures have been elucidated using nuclear magnetic resonance (NMR) and mass spectrometry (MS). All Nod factors characterized to date have a common structure which consists of an oligosaccharide backbone of $\beta 1-4$ linked $N$-acetyl-D-glucosamine (GlcNAc) residues, with a fatty acid group attached to the nitrogen of the nonreducing terminal residue. Due to the
糖合成酵素間で配列に類似性があるという指摘によるものであ る(4-6)。Nod C と構造的に最も近縁な酵素は次の上うな物質の 合成を行う転移酵素である。(i)キチン； $\beta$ 1-4結合したN-アセチ ルグルコサミン(GlcNAc)残基のポリマー。カビの細胞壁や甲殻 類や昆虫の外骨格中に存在する。(ii)セルロース； $\beta$ 1-4結合した ブドウ糖(Glc)残基のポリマー。高等植物や藻類の細胞壁中に存 在し、またある種の細菌も生産する。(iii)ヒアルロン酸(ヒアル ロナンとしても知られる)；[GlcNAc- $\beta$ 1-4-GlcA- $\beta$ 1-3] 反復工 ニットにおけるGlcNAcとグルクロン酸(GlcA)のコポリマー。動 物の細胞外マトリックスの構成成分である。(iv)ゼブラフィッ シュ胚発生初期のキチンオリゴ糖。キチンやセルロースといっ た多糖は地球上の生物性ポリマーの大部分を占めているが、そ れらの生合成の基本的な性質はよくわかっていない。根粒菌の タンパク質NodCによるキチンオリゴ糖の生合成は最近試験管内 で解析されており、この酵素に関する構造-機能解析が現在進行 中である。Nod Cタンパクは以下の3つの特徽によって、この ファミリーに属する酵素の構造と機能の関係を研究するための 有用な対象である。(i)複数の根粒菌種からnod C 遺伝子がクロー ン化されている。(ii)Nod Cは菌の生存に必須の酵素ではないの で、 $\beta-$ 多糖合成酵素の他のメンバーの多くのものでは不可能な 突然変異解析を行うことができる。(iii)生成物が多糖ではなく才 リゴ糖なので、酵素生成物の解析を簡単に行うことが可能であ る。以下、NodCによるキチンオリゴ糖生合成のモデルと $\beta-$ 多 糖合成酵素ファミリーに共通な構造について述べる。6種類の保 存された領域を示し、それらの可能な機能を、基質結合性、触 媒反応および生成糖鎖長の制御に関連して議論する。

\section{B. 根粒菌の根粒形成タンパクNod Cによるキチンオリゴ糖生合} 成

マメ科植物はRhizobium、Sinorhizobium、Mesorhizobium、

Bradyrhizobium、Azorhizobium に属する土壇細菌(まとめて根粒 菌と呼ぶ)と共生関係を成立させる。この共生はマメ科植物に根 粒を形成し、その中で根粒菌は大気窒素をアンモニアに還元す る。宿主植物の根の分泌物中に含まれるフラボノイドに反応し て、根粒菌はNod ファクターと呼ばれるシグナル物質を分泌す る。Nodファクターは当初、宿主植物に根毛の変形を誘導する 物質として単離された。今日では、Nod ファクターは多くの根 粒菌から精製されており、それらの構造が核磁気共鳴および質 量分析によって明らかにされている。これまでに解析された Nodファクターはすべて共通の基本構造を持っており、それは $\beta$ 1-4結合した N-アセチルグルコサミン(GlcNAc)残基のオリゴ糖 骨格の非還元末端の窒素に脂肪酸が付いた構造である。オリゴ 
structural resemblence of the oligosaccharide backbone to chitin, the polymer of $\beta 1-4$ linked GlcNAc, the Nod factors have been designated lipochitin oligosaccharides. The biosynthesis of rhizobial lipo-chitin oligosaccharides involves the action of several enzymes encoded by the so-called nodulation genes [reviewed in (8)]. The nodC gene is one of the three genes that together are sufficient for the synthesis of a lipo-chitin oligosaccharide core-structure (9). Heterologous expression of Rhizobium leguminosarum biovar viciae NodC in Escherichia coli results in the synthesis of chitin oligosaccharides in vivo (10, 11). It is therefore clear that the function of NodC in Nod factor biosynthesis is to catalyze the formation of chitin oligosaccharides. More recent results have shown that NodC also produces chitin oligosaccharides after expression in the yeast Saccharomyces cerevisiae, both in vivo and in vitro (J. Bakkers, personal communication and E. Kamst, unpublished results). This observation indicates that no bacterium-specific substrate or protein beside NodC is necessary for the formation of chitin oligosaccharides.

\section{B-1. Chitin Oligosaccharide Chain-Initiation by NodC}

The biosynthesis of oligo- and polysaccharides is generally initiated on (glyco)lipids or (glyco)proteins, such as $\mathrm{N}$ acetylglucosamine-pyrophosphoryl-dolicholphosphate and the related $N$-acetylglucosamine-undecaprenylphosphate (the precursors in eukaryotic protein glycosylation and bacterial cellwall biosynthesis, respectively) (12), and the proteins which autoglucosylate themselves in the initiation of starch- $(13,14)$ and glycogen-biosynthesis $(15,16)$. However, NodC-dependent lipid-linked intermediates were not detected following established extraction procedures $(11,17)$. The antibiotics tunicamycin, amphomycin, and bacitracin specifically inhibit the formation of $\mathrm{N}$-acetylglucosamine-pyrophosphoryldolicholphosphate (18), but do not affect chitin oligosaccharide formation, showing that dolichol-phosphate-linked intermediates are not involved in the biosynthesis of chitin oligosaccharides by $\operatorname{NodC}(11,17)$.

\section{B-2. Direction of Chitin Oligosaccharide Chain-Elongation by NodC and DG42}

Elongation of the growing chitin oligosaccharide chain by NodC proceeds by the addition of monosaccharides to $O 4$ of the nonreducing-terminal GlcNAc residue. This was shown by the observation that NodC is able to synthesize chitin oligosaccharides using either free GlcNAc or GlcNAc- $\beta 1$ - $p$-nitrophenyl (pNPGlcNAc) as a primer (17). The same study has shown that chitin oligosaccharides ranging from chitinbiose to chitintetraose are incapable of acting as efficient primers for NodC. These results indicate that chitin oligosaccharide synthesis by NodC occurs by a processive mechanism: in such a mechanism, successive addition of saccharide units to a growing chain only proceeds while the enzyme remains continuously in close contact with the oligosaccharide; prematurely dissociated oligosac-
糖骨格と 及 1-4結合したGlcNAcのポリマーであるキチンの構造的 な類似性により、Nodファクターはリポキチンオリゴ糖と呼ばれ ている。根粒菌のリポキチンオリゴ糖の生合成には、いわゆる 根粒形成遺伝子によりコードされたいくつかの酵素が関わって いる[(8)にレビューされている]。NodC遺伝子はリポキチンオリ ゴ糖の中心骨格の合成に必要な3つの遺伝子のうちの1つである (9)。Rhizobium leguminosarum biovar viciae のNod Cを大腸菌で 異種発現させたところ、in vivoでキチンオリゴ糖の合成を引き起 こした(10、11)。このことから、Nodファクター合成における $\operatorname{Nod} C$ 遺伝子の機能はキチンオリゴ糖の形成を触媒する事である ことが明らかとなった。より最近の結果によれば、Nod Cを酵母 Saccharoomyces cerevisiaeで発現させるとin vivo およびin vitroの 両方でキチンオリゴ糖を生成する(J. Bakkers 私信、および E.Kamst未発表結果)。この結果はキチンオリゴ糖合成にはNod C 以外の細菌特異的な基質やタンパク質は必要ないことを示して いる。

\section{B-1. Nod Cによるキチンオリゴ糖鎖の合成開始}

オリゴ糖あるいは多糖の生合成は通常(糖)脂質か(糖)タンパ ク上で開始される。例えば、N-アセチルグルコサミン-ピロリン 酸-ドリコールリン酸とその同族のN-アセチルグルコサミン-ウン デカプレニルリン酸(それぞれ真核生物のタンパク質の糖鎖付加 および細菌の細胞壁生合成の前駆体)(12)、デンプン生合成(13、 14)とグリコーゲン生合成(15、16)の開始時に糖を結合する(自己糖 鎖化する)タンパク質などがそうである。しかしながら、これま でに確立された抽出手法によっては、NodC依存性の脂質に結合 した中間体は検出されなかった(11、17)。ツニカマイシン、アン フォマイシン、バチトラシンといった抗生物質は $N$-アセチルグ ルコサミンーピロリン酸ードリコールリン酸の形成を特異的に阻害 する(18)が、キチンオリゴ糖の生成には影響しない。このこと は、ドリコールリン酸に結合した中間体はNod Cによるキチンオ リゴ糖の生合成には関与しないことを示している $(11 、 17) 。$

\section{B-2. Nod CとDG42によるキチンオリゴ糖の伸長}

Nod Cによるキチンオリゴ糖鎖の伸長はGlcNAc非還元末端 のO4に対する単糖の付加により進行する。このことは Nod Cが 遊離GlcNAcやGlcNAc- $\beta$ 1-p-ニトロフェニル(pNPGlcNAc)をプラ イマーとして用いてキチンオリゴ糖を合成することができると いう知見により示された(17)。同じ研究で 2 ないし 3 残基から なるキチンオリゴ糖はN Nod C の効果的なプライマーとして働か ないことが示されている。つまり、NodCによるキチンオリゴ糖 合成はプロセッシブな機構により行われていると考えられる。 このような機構のもとでは伸長する糖鎖に対する単糖の連続し た付加が進行するのは、生成途上のオリゴ糖と酥素が緊密に接 触している間のみであり、途中で酵素と解離してしまったオリ 
charides are not further elongated.

The nature of the enzymatic activity of the DG42 protein (Fig. 2) is currently a matter of debate (19). There are investigators who have shown a DG42-dependent chitin oligosaccharide synthase activity (20-22), whereas others have concluded that DG42 is involved in hyaluronic acid synthesis $(23,24)$. We used the artificial glycosyl acceptor GlcNAc-1-O-p-nitrophenyl to investigate the direction of chitin oligosaccharide synthesis by zebrafish embryo extracts and showed that it is the same as we found for NodC; elongation occured by addition of monosaccharides to $O 4$ of the nonreducing-terminal residue (17). Interestingly, elongation of growing hyaluronic acid chains in mammalian cells has been reported to take place at the reducingterminal residue (25) which is opposite to what we showed for the DG42-dependent formation of chitin oligosaccharides by zebrafish embryos. It seems unlikely that DG42 can catalyze both these reactions. Our data therefore support the notion that DG42 encodes a chitin oligosaccharide synthase, rather than a hyaluronic acid synthase.

\section{B-3. Chitin Oligosaccharide Chain-Length Control by NodC}

The length of the oligosaccharide backbone in lipo-chitin oligosaccharides produced by different rhizobia varies between two and six residues. The analysis of chitin oligosaccharides produced by E.coli strains containing the cloned nodC genes of M.loti, S.meliloti, or R.l. bv viciae shows that the length of the major oligosaccharide produced by each NodC protein corresponds with the oligosaccharide of the major LCOs of the corresponding rhizobial strain (26). It is therefore clear that the regulation of chitin oligosaccharide chain-length is an intrinsic feature of NodC proteins.

\section{B-4. The Chitin Oligosaccharide Biosynthesis Pathway: a Model}

A $\beta 1-4$ linkage between two monosaccharide residues dictates that the residues are turned $180^{\circ}$ with respect to each other. This has led to discussions about the possibility that $\beta$ polysaccharides are synthesized by the simultaneous coupling of two monosaccharide residues to a growing chain, thereby removing the necessity of rotation of either the growing chain or the enzyme $(3,27)$. Saxena et al. (3) recently proposed such a mechanism in a general model for the synthesis of $\beta 1-4$ oligosaccharides and polysaccharides by processive glycosyltransferases. In this model elongation was assumed to proceed from the reducing terminus of the growing polymer. The growing chain was proposed to interact with the active site of a polysaccharide synthase via a UDP moiety at the reducing terminus. However, as discussed above, this is not the case for chitin oligosaccharide biosynthesis by NodC proteins. Moreover, the "two residue addition model" of Saxena and coworkers makes it difficult to explain the formation of chitinbiose and chitintetraose by NodC. We therefore propose an alternative model for the biosynthesis of chitin oligosaccharides, depicted
ゴ糖はそれ以上伸長しない。

DG42タンパク(図2)の酵素的性質は現在論議されている最中 である(19)。DG42依存的なキチンオリゴ糖合成酵素活性を示し た研究者もいるが (20-22)、DG42はヒアルロン酸合成に関与し ているのだと結論する者もいる $(23 、 24)$ 。我々は人工の糖受容体 GlcNAc-1-O-p-ニトロフェニルを用い、ゼブラフィッシュ胚抽出 液によるキチンオリゴ糖合成の方向を調べたところ、NodCで見 られたのと同じであることが示された。すなわち、伸長は非還 元末端残基のO4に対して単糖が付加することによりおこってい た(17)。面白いことに、動物細胞中でのヒアルロン酸鎖の伸長は 還元末端でおこると報告されている。これは、ゼブラフィッ シュ胚によるDG42依存的キチンオリゴ糖の生成で示されたのと 反対である。DG42が両方の反応を触媒するということはありそ うにないので、我々のデータはDG42はヒアルロン酸合成酵素で はなく、キチンオリゴ糖合成酵素をコードするという考えを支 持しているといえる。

\section{B-3. Nod Cによるキチンオリゴ糖鎖の長さの制御}

様々な根粒菌により生成されるリポキチンオリゴ糖におけ るオリゴ糖骨格の長さは2残基から6残基の間である。M.loti、

S.meliloti、あるいはR.l.bv viciaeからクローン化されたNod Cを 保持する大腸菌により生成するキチンオリゴ糖の分析により、 それぞれのNodCタンパクにより生成された主なオリゴ糖の長さ はそれと対応する根粒菌の主なLCOのオリゴ糖と対応していた (26)。このことからキチンオリゴ糖の糖鎖長の制御はNod Cタン パク固有の性質によるということが明らかである。

\section{B-4. キチンオリゴ糖生合成経路：モデル}

2つの単糖残基間の $\beta$ 1-4結合により、残基はお互いに対し て180度ねじれた位置関係になる。このことから、 $\beta$ 多糖の合成 は伸長中の糖鎖に対して2個の単糖残基が同時にカップリングす ることによって行われ、それによって伸長中の糖鎖または酵素 が(反応のたびに)回転する必要性から免れているという考えがあ る(3、27)。Saxenaら(3)は最近、プロセッシブな糖転移酵素によ る $\beta 1-4$ オリゴ糖と多糖合成の普遍的なモデルとしてそのような 機構を提案した。このモデルでは、伸長反応は、伸長するポリ マーの還元末端から進行すると仮定され、伸張する糖鎖は還元 末端でUDP部分を通じて多糖合成酵素の活性部位と相互作用す ると提案された。しかし、上に述べたように、このモデルは Nod Cタンパク質によるキチンオリゴ糖合成にはあてはまらな い。さらに、Saxenaらによる「2残基付加モデル」ではNodCに よるキチン 2 糖やキチン 3 糖の生成を説明することが困難であ る。このことから、我々は図1で示したような、キチンオリゴ糖 生合成の新たなモデルを提案する。このモデルでは単糖が伸長 する糖鎖の非還元末端に付加される。1つの基質結合部位は糖又 


\begin{abstract}
Fig. 1. A model for the mechanism of chain elongation by NodC. The NodC protein is schematically represented by three binding-sites that mediate the interaction with the GlcNAc-donor UDP-GlcNAc, with the glycosyl-accepting GlcNAc residue, and with the elongated product, respectively. Binding of UDP-GlcNAc is followed by transfer of the monosaccharide from UDP-GlcNAc to the GlcNAc molecule at the acceptor-binding site, immediately followed by a translocation step. In each following step, UDP-GIcNAc binding is followed by liberation of UDP, linkage of GlcNAc to $O 4$ of the non-reducing terminal GlcNAc residue of the growing oligosaccharide, and immediate translocation of the elongated product. In this way, the donor-binding site is contstantly available for binding of UDP-GlcNAc. When the oligosaccharide reaches the maximal length, controlled by the folding of NodC, dissociation of the saccharide from NodC follows, and NodC becomes available for the synthesis of another chitin-oligosaccharide molecule. Experimental data on which this model is based are discussed in detail in the text. $X$ represents either one or more $\beta 1-4$ linked GlcNAc residues, a free hydroxyl-group, or a glycosidicallylinked hydrophobic aglycone.
\end{abstract}

in Fig. 1. In this model, monosaccharides are added to the nonreducing-terminal residue of a growing chain. One substratebinding site interacts with the nucleotide-sugar, and a second site is required for binding of the nonreducing-terminal residue of the glycosyl acceptor. A third binding site interacts with the growing chain and allows the chain to be translocated following elongation. This site can therefore be regarded as a productbinding site, or processivity-domain. GlcNAc-X in Fig. 1 represents either a growing chitin oligosaccharide chain (in which case $\mathrm{X}$ represents one or more $\beta 1-4$ linked GlcNAc residues), one of the reported primers for chitin oligosaccharide synthesis in vitro (in which case $\mathrm{X}$ represents a hydroxyl group, or a $p$ nitrophenyl moiety), or an unknown natural primer.

\section{Functional Domains in NodC and Related $\beta$-Polysaccha- ride Synthases}

We performed a detailed sequence analysis of $\beta$-polysaccharide synthases which revealed the presence of six conserved sequences present in all members (Fig. 2). Most of these regions have been reported earlier, but region 4 has not been recognized as a conserved sequence in these enzymes before. All six conserved regions are flanked by membrane-spanning domains. Spacing between regions varies except for regions 5 and 6 which are consistently seperated by 31 amino acids. Bacterial- and eukaryotic-members of the hyaluronic acid synthases and the cellulose synthases differ in that the eukaryotic enzymes contain additional sequences (compare for instance CelA and RSW1 in Fig. 2). These additional sequences have been suggested to play a role in regulating intracellular localization and possible interactions with other proteins which may occur in a species-specific manner.

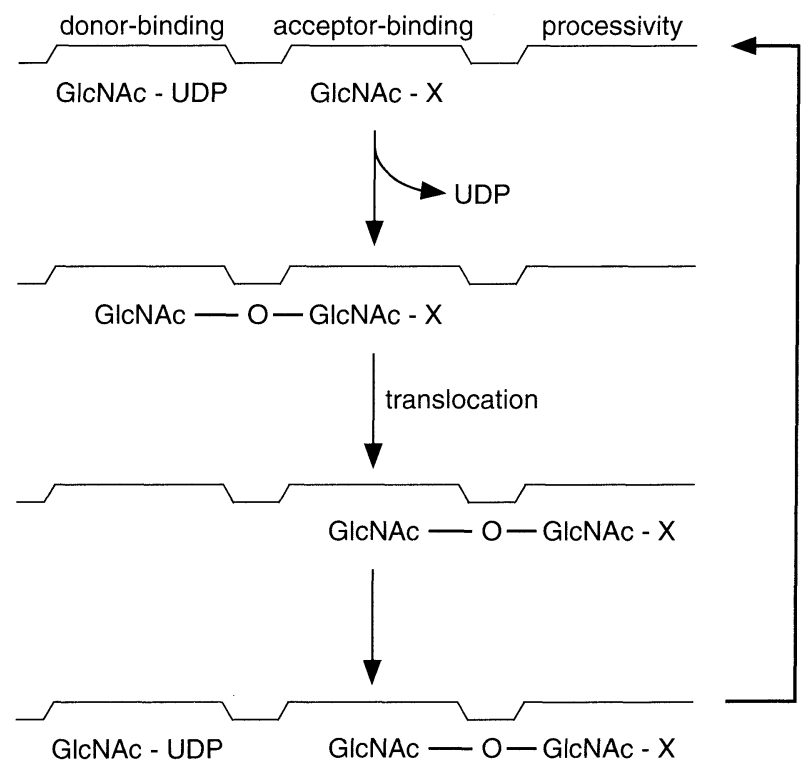

クレオチドと相互作用し、2番目の部位は糖受容体の非還元末端 残基との結合に必要である。3つ目の結合部位は伸長する糖鎖と 相互作用し、糖鎖が伸長した後、転移できるようにする。この ため、この部位は産物結合部位あるいはプロセッシビティドメ インと呼ぶことができる。図1でGlcNAc-Xは伸張するキチンオ リゴ糖鎖(この場合、Xは1つ以上の $\beta$ 1-4結合したGlcNAc残基）

か、in vitroでのキチンオリゴ糖合成について報告されているプ ライマー、あるいは未知の本来のプライマーを表している。

C. Nod Cと近縁の $\beta$-多糖合成酵素の機能ドメイン $\beta$-多糖合成酵素の詳細な配列解析を行ったところ、すべて のメンバーに存在する6つの保存された配列の存在が明らかと なった(図2)。この領域のほとんどは以前に報告されていたもの であるが、領域4は、これらの酵素で保存された配列とは従来認 識されていなかったものである。6つの保存領域はすべて膜貫通 ドメインと隣接している。領域間の距離は領域5と6の間を除い ては様々である。領域5と6の間は常に 31 アノ酸隔てられてい る。ヒアルロン酸合成酵素とセルロース合成酵素の細菌と真核 生物のメンバーは真核生物の酵素に余分な配列があるという点 で違いがある(図2のCelAとRSW1を比較)。これらの余分な配列 は細胞内局在の制御や種特異的に起こりうる他のタンパク質と の何らかの相互作用に関連すると考えられている。 


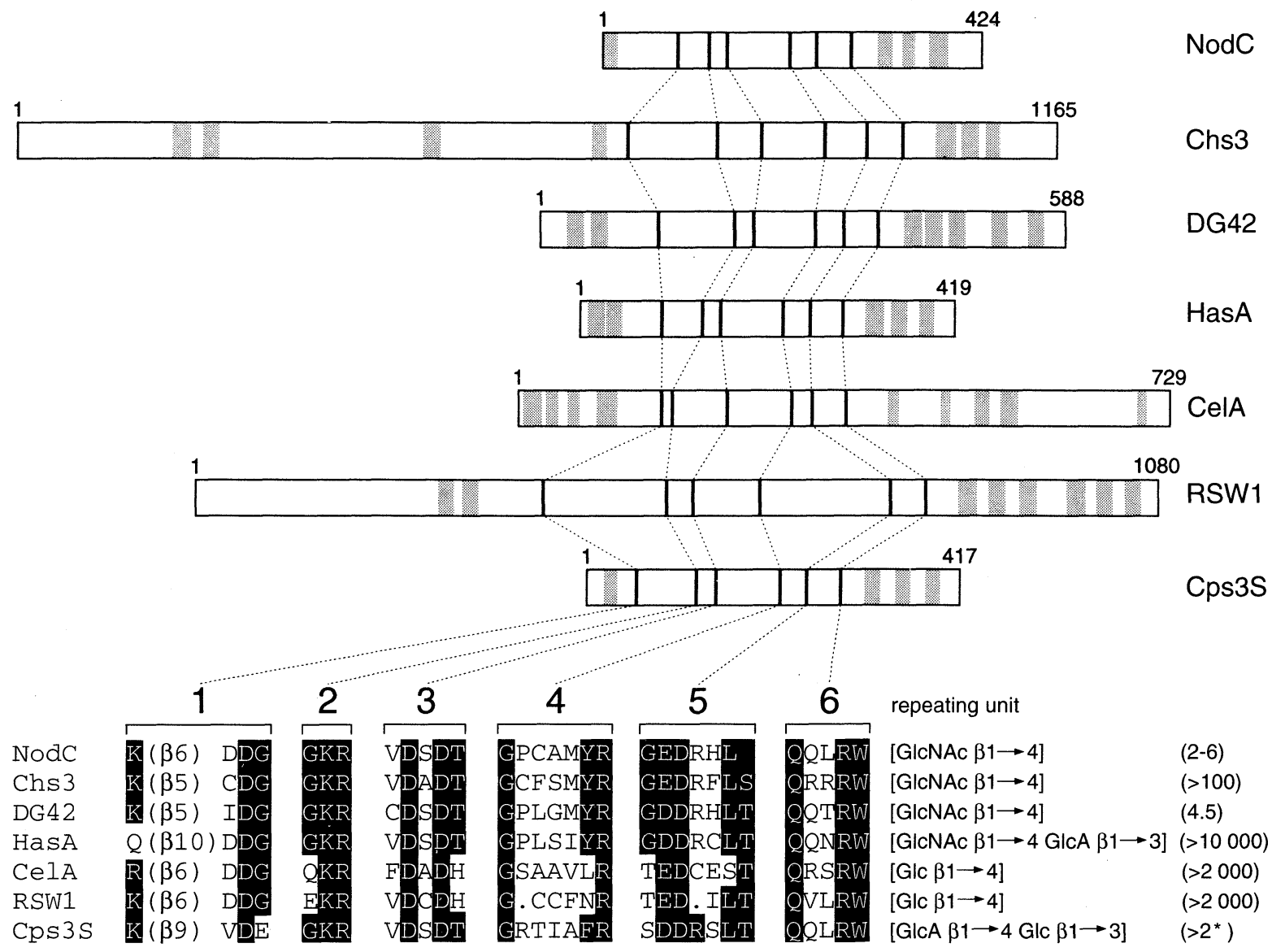

Fig. 2. Conserved regions in $\beta$-polysaccharide synthases. Horizontal bars in the upper left represent the various proteins, and the number of amino acids in each protein is given at the right end of each bar. The black vertical bars indicate the positions of the sequences that are conserved throughout the entire family. These sequences are shown at the bottom of the figure. The names and the repeating units of the oligosaccharides or polysaccharides which are produced by the different enzyme are listed on the bottom right. Reported product lengths are given between brackets. *: this is the minimum value reported, but the polymer maybe as long as several hundred units depending on strains and culture-conditions. Transmembrane regions are shown in grey and were predicted using the TopPred 2 program and the DAS transmembrane prediction server at http://www.biokemi.su.se/ server (Stockholm University, Sweden), the TMpred program (Swiss Institute for Experimental Cancer Research, Epalinges, Switzerland), and PhdTopology program (EMBL, Heidelberg University, Germany) via the BCM server at http://kiwi.imgen.bcm.tmc.edu:8088/search-launcher/launcher.html (Baylor College of Medicine, Houston, TX). The proteins shown are: NodC, M.loti nodulation protein (accession no X01650;(40); Chs3, Saccharomyces cerevisiae chitin synthase 3 encoded by the CSD2/CAL1 gene (accession no P29465; (41); DG42, Xenopus laevis developmental protein (accession no P13563; (42); HasA, Streptococcus pyogenes hyaluronan synthase (accession no L20853; (43); CelA, Agrobacterium tumefaciens cellulose synthase (accession no L38609; (44); RSW1:Arabidopsis thaliana cellulose synthase (accession no AF027172);(52); Cps3S, Streptococcus pneumoniae type 3 capsular polysaccharide synthase (accession no U15171; (45). Abbreviations for monosaccharides are : GlcNAc, $N$-acetylglucosamine; Glc, glucose; GlcA, glucuronic acid.

\section{C-1. Membrane Topology}

All members of the $\beta$-polysaccharide synthase family contain several hydrophobic regions and are predicted to be membrane proteins. A membrane-localization has directly been shown for most members. A prediction of trans-membrane regions in members of the $\beta$-polysaccharide synthases and the structure of their respective products is depicted in Fig. 2. Analysis of a series of NodC-PhoA fusion proteins has confirmed the presence of trans-membrane regions as shown in Fig. 2, and provided direct evidence that the domain containing the six con-

\section{C-1. 膜のトポロジー}

$\beta$-多糖合成酵素ファミリーのすべてのメンバーはいくつか の疎水性領域をもっており、膜タンパク質であると推定されて いる。膜局在性はほとんどのメンバーで直接的に証明されてい る。 $\beta$-多糖合成酵素メンバーの膜貫通領域であると予測される 部分とそれらの類縁タンパク質の構造を図 2 に示した。一連の Nod C-PhoA融合タンパク質の解析により図 2に示された膜貫通 領域の存在が確認され、6つの保存された領域を含むドメインは 


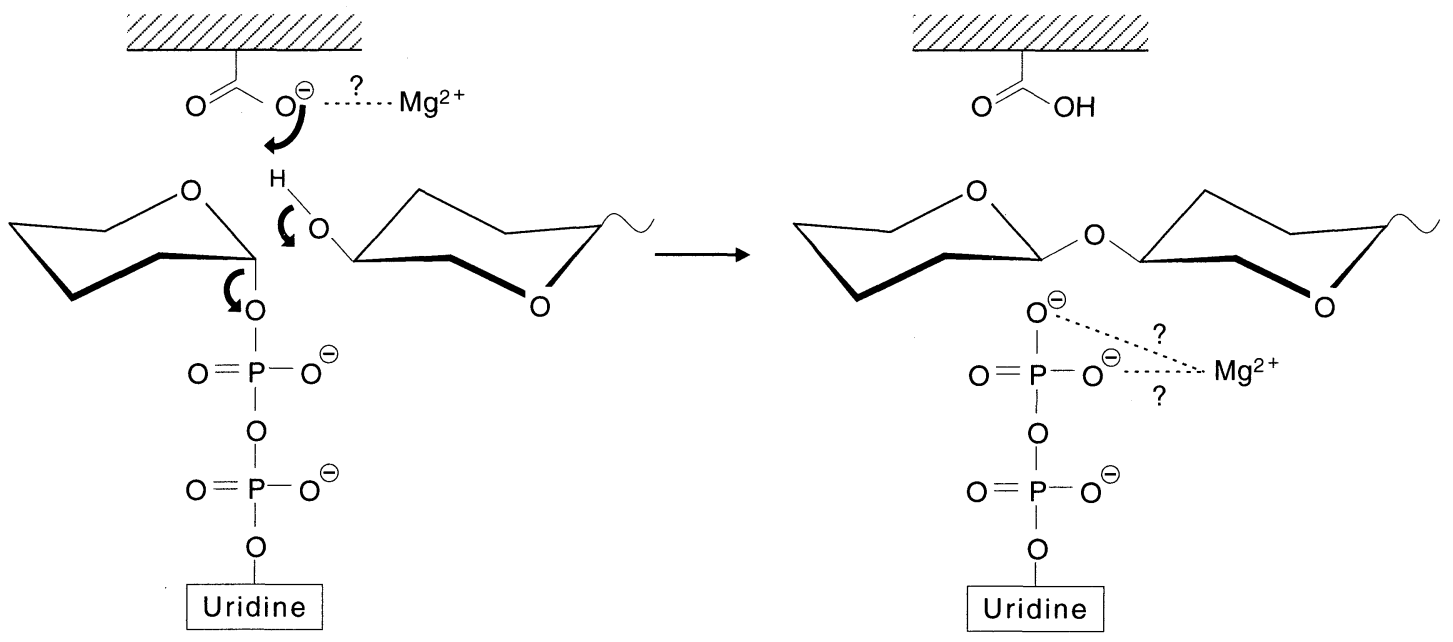

Fig. 3. Mechanism of $\beta$-glycosyl transfer. The mechanism depicted leads to the formation of a $\beta$-glycosidic linkage from an $\alpha$-linked saccharide donor (inversion), and has been proposed based on the mechanism of glycosyl hydrolysis (46).

served regions is cytoplasmic.

\section{C-2. Possible Catalytic Residues}

Since UDP is $\alpha$-linked in UDP-monosaccharides, $\beta$ polysaccharide synthases including NodC must catalyze the glycosyl transfer reaction using a so-called inverting mechanism (Fig. 4). In such a mechanism, a catalytic base (proton-acceptor) is expected to be the only required catalytic residue. Asp and Glu residues are thus candidates for such a function. Divalent cations have been reported to be essential for the enzymatic activity of several phosphodiesterases and are believed to participate in the enzyme reaction by either activating the catalytic residue and/or stabilizing the negative charge on the phosphate leaving-group (Fig. 3), as was suggested for the mechanism of the exonuclease activity of the Klenow fragment (28). A similar role for $\mathrm{Mg}^{2+}$ in the reaction catalyzed by the DNA-modifying $\beta$-glucosyltransferase of bacteriophage T4 (T4$\beta$ GlcT) is suggested by the observation that this cation is not required for UDP-Glc binding (29), but nevertheless is essential for enzyme activity (30). Based on crystallopgraphic data, $\mathrm{Asp}^{258}$ in T4- $\beta$ GlcT has been proposed to be involved in $\mathrm{Mg}^{2+}$ binding (29), and is therefore likely to be directly involved in catalysis. This Asp residue in T4- $\beta$ GlcT corresponds to the conserved Asp in region 2 of the $\beta$-polysaccharide synthases, which may therefore also be involved in $\mathrm{Mg}^{2+}$ binding and is most likely to be the catalytic residue.

\section{C-3. Substrate Binding Sites}

In 1982, Walker and co-workers defined two amino acid sequence motifs which together form the so-called Rossmannfold for mono- or di-nucleotide binding $(31,32)$ (depicted in Fig. 4). One of these motifs was originally called motif-A but is nowadays better known as the P-loop. This strand-loop-he-
細胞質側にあるという直接的な証拠が示された。

\section{C-2. 可能な触媒残基}

UDP-単糖においてUDPは糖と $\alpha$ 結合しているので、Nod C を含む $\beta$ 多糖合成酵素は糖転移反応をいわゆる逆転移機構を用 いて触媒する(図4)。そのような機構では、触媒塩基 (プロトン 受容体)が唯一の必要な触媒残基であると期待される。このた め、AspとGlu残基はそのような機能を担う候補である。2価陽イ オンはいくつかのホスホジエステラーゼの酵素活性に必須であ ると報告されており、Klenow fragmentのエキソヌクレアーゼ活 性の機構で提案されているように(28)、触媒残基を活性化するか 脱りン酸化された分子団の負電荷を安定化することにより(図 3)、酵素反応に参加すると信じられている。DNAを修飾する T 4バクテリオファージの $\beta$-糖転移酵素(T4- $\beta$ GlcT)によって触媒 される反応においても $\mathrm{Mg}^{2+}$ に類似の役割があるということが、 この陽イオンはUDP-Glcの結合には必要ない(29)が、にもかかわ らず酵素の活性化には必須である(30)ということから提案されて いる。結晶解析のデータに基づき、T4- $\beta$ GlcT中のAsp ${ }^{258}$ が $\mathrm{Mg}^{2+}$ との結合に関与していることが提案され、このため、Asp $\mathrm{As}^{258}$ が直 接的に触媒作用に関わっている可能性が高い。T4- $\beta$ GlcT中のこ のAsp残基は $\beta$-多糖合成酵素の領域2の保存されたAspに対応す る。そこで、この残基もまた $\mathrm{Mg}^{2+}$ 結合に関与しており、触媒残 基である可能性が最も高い。

\section{C-3. 基質結合部位}

1982年にWalkerたちは1つあるいは2つのヌクレオチドと結 合するいわゆるRossmannの折り畳み部位(Rossmann fold)を形成 する2つのアミノ酸配列モチーフを決定した(31、32)(図4に記 述)。これらのモチーフの 1 つはもともとはモチーフAと呼ばれて 
Walker-A / P-loop motif

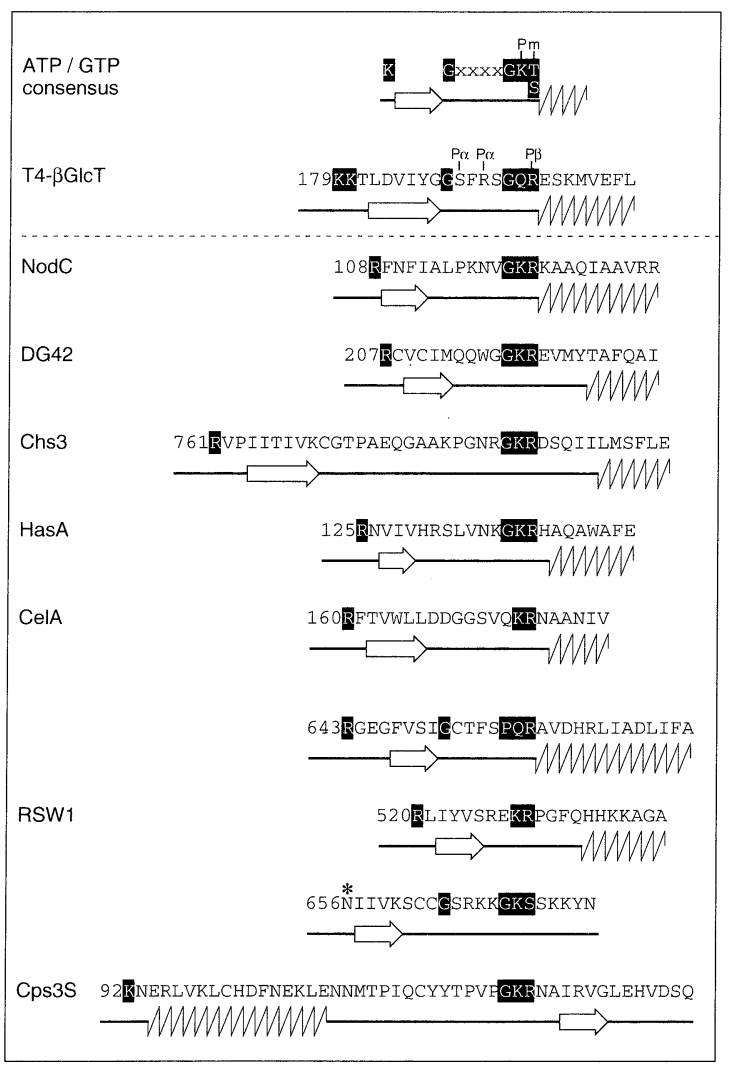

Walker-B motif

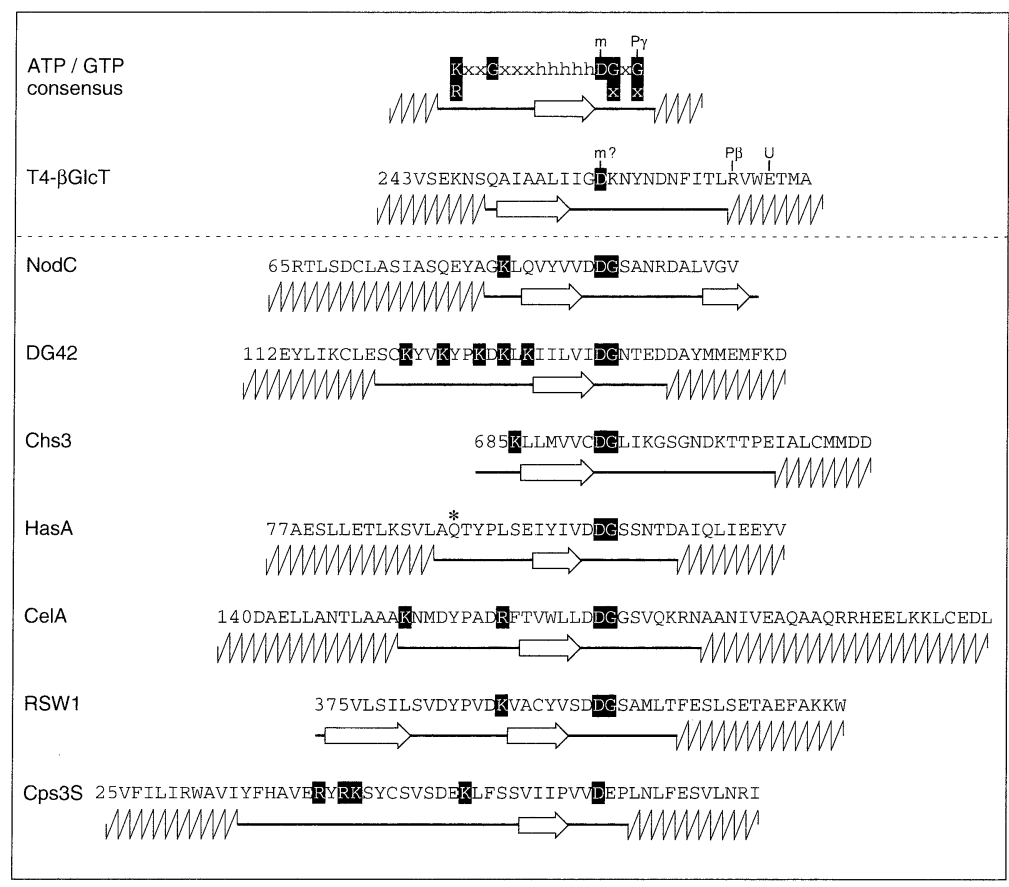

$\longrightarrow-\beta$-strand

-WMWL : $\alpha$-helix

Fig. 4. Nucleotide binding motifs in $\beta$-polysaccharide synthases. Proteins shown are bacteriophage T4 $\beta$-glucosyltransferase T4- $\beta$ GlcT (P04547), and the proteins listed in Fig. 3. The structural elements in T4- $\beta$ GlcT are derived from the crystallographic study of (29). Protein secondary structure predictions were obtained using six different methods (47-52). Application of these programs was performed at the following servers: http://www.ibcp.fr/serv_pred.html (Institute of Biology and Chemistry of Proteins CNRS-UPR, Lyon, France) and http://kiwi.imgen.bcm.tmc.edu:8088/search-launcher/launcher.html (Baylor College of Medicine, Houston, TX). Individual amino acids that have been shown to interact with phosphate (P), divalent metal ions (m), or uridine (U) are indiciated. Residues that correspond to the known nucleotide binding motifs in ATP/GTP-binding proteins are marked by a black background. Two amino acid residues in HasA and RSW1 are labeled with * to indicate that they may serve a similar role as the conserved lysine/ariginine residues in the classical walker-motifs. The GKS sequence in the P-loop motif in RSW1 is in a loop of 60 amino acids. Different programs yield contradicting predictions for this loop to be followed by an $\beta$-helix or $\beta$-strand. A similar uncertainty applies to the region preceeding the Walker-B motif in Chs3.

lix motif contains the consensus sequence GXXXXGK[T/S] in the loop. It is conserved in many nucleoside-triphosphate-binding enzymes where it interacts with the phosphate groups (see $(33,34)$ for reviews on P-loop sequences and structures). Until recently, P-loops were only known to be present in nucleosidetriphosphate-utilizing proteins such as hydrolases, transmembrane transporter systems, and kinases. Vrielink and co-workers, however, recently also detected a P-loop structure in the threedimensional structure of a glycosyltransferase: the DNA-modifying $\beta$-glucosyltransferase of bacteriophage T4 (T4- $\beta$ GlcT) (29). Arginine $^{191}$ and the arginine in the GQR motif in the P-loop of T4-BGlcT (depicted in Fig. 4) were shown to interact directly with the $\alpha$ - and $\beta$-phosphates of the bound UDP-glucose by these investigators. Here we report that a similar sequence (GKR) is conserved in the $\beta$-polysaccharide synthase family (Fig. 4). The
いたが、現在ではP-loopとしてよく知られている。このstrandloop-helixモチーフはloopの中にGXXXXGK[T/S]というコンセン サス配列を含んでいる。それは多くのヌクレオチド3リン酸結 合酵素に保存されており、リン酸基と相互作用する(P-loopの配 列と構造の総説は $(33 、 34)$ を参照 $)$ 。最近まで、P-loopは加水分解 酵素、膜貫通輸送系、リン酸化酵素のようなヌクレオチド3リ ン酸を利用するタンパク質に存在することが知られているのみ であった。しかしながら、V rielinkらは最近、P-loop構造を、 DNAを修飾するバクテリオファージT4の $\beta$ 糖転移酵素 $(\mathrm{T} 4-\beta$ GlcT)の3次元構造中にも検出した(29)。これらの研究者たちに より、アルギニン191とT4- $\beta$ GlcTのP-loop中のGQRモチーフの アルギニン(図4)は結合したUDP-グルコースの $\alpha$-および $\beta$-リン 酸と直接相互作用することが示された。我々はここで、類似し た配列(GKR)が $\beta$-多糖合成酵素ファミリーに保存されているこ とを指摘したい(図4)。この領域の予測される2次構造と側鎖に 
predicted secondary structure of this region and the presence of several amino acids with an amino- or hydroxy-group in their side chains are homologous to the classical P-loop. Note that the cellulose synthases are the only members that contain two P-loop motifs, which is in agreement with the hypothesis that cellulose synthases may contain two UDP-glucose binding sites (27).

In addition to the P-loop, several nucleotide-binding enzymes also contain a conserved structure originally defined as motif $\mathrm{B}$, that is also part of the nucleotide-binding fold (32). This element consists of a $\beta$-strand with a conserved Asp at the C-terminal position (Fig. 4). An arginine or lysine typically preceeds this strand. The conserved Asp in motif-B has been reported to be involved in $\mathrm{Mg}^{2+}$-binding $(29,34)$. Other studies have shown that motif-B is also involved in binding the $\beta$-phosphate of nucleoside-triphosphates via the main-chain amide nitrogen of the conserved glycine indicated in Fig. 4 (35-37). We have previously reported a weak similarity between a region in the chitin oligosaccharide synthase NodC, and the motif-B consensus sequence (38). In Fig.4 we show the predicted secondary structure of this region in NodC and related $\beta$-polysaccharide synthases. Our analysis shows that this region in NodC is conserved among members of the $\beta$-polysaccharide synthase family, and that it is homologous to the nucleotide-binding B-motif described above.

It is evident that the sequence of the elements in $\beta$ polysaccharide synthases described here differ from those in the originally-defined P-loop and motif-B in ATP/GTP-binding proteins. These differences are not surprising. Even within the family of kinases there are marked differences in P-loop sequence; phosphoglycerate kinases contain the GG[A/S $]$ KVXXK motif, rather then the GXXXGK[T/S] found in other kinases $(33,34)$.

In conclusion, our results indicate that the Rossmannnucleotide binding fold is not only present in nucleoside-triphosphate-binding proteins, but is also conserved in the $\beta$-polysaccharide synthase family. The sequence analysis reported here provides a theoretical basis for a detailed mutational analysis to further investigate the role of these motifs in the binding of nucleotide-sugar donors.

Region 3-like motifs are not only present in $\beta$-polysaccharide synthases, but also in nonprocessive $\beta$-glycosyltransferases $(3,39)$. The nonprocessive transferases analyzed by Saxena et al. (3) include a glycosyltransferase involved in the synthesis of mannosyl-diphospho-dolichol, so that the acceptor used by this enzyme is not a saccharide, but the lipid dolicholpyrophosphate. It therefore seems unlikely that the conserved region 3 is involved in acceptor-binding and it probably plays a role in the interaction with the glycosyl-donor.

Indications as to the function of regions 4 and 5 come from our comparison of the amino acid sequences of these regions in the $\beta$-polysaccharide synthases with conserved amino
アミノ基あるいは水酸基をもついくつかのアミノ酸の存在が古 典的なP-loopと相同である。注目すべきことに、セルロース合成 酵素は2つのP-loopモチーフをもつ唯一のメンバーであり、この ことはセルロース合成酵素が2つのUDP-グルコース結合部位を もっているかもしれないという仮説(27)と一致している。

P-loopに加え、いくつかのヌクレオチド結合酵素はまた、も ともとはモチーフBとして定義されたヌクレオチド結合フォール ド(32)の一部である保存された構造をもつ。このエレメントはC 末端側に保存されたAspをもつ $\beta$ 鎖からなる(図4)。アルギニン やリジンがこの鎖の前に位置するのが一般的である。モチーフ B中の保存された $\mathrm{Asp} \mathrm{Mg}^{2+}$ との結合に関与していると報告され た(29、34)。他の研究から、モチーフBはまた、図4に示された 保存されたグリシンの主鎖のアミド窒素を通じたヌクレオチド 3リン酸の $\gamma$ 位リン酸との結合に関与していることが示された (35-37)。我々が以前報告したように、キチンオリゴ糖合成酵素 Nod Cのある領域とモチーフBのコンセンサス配列の間には弱い 類似性がある(38)。図4中にNod C と近縁の $\beta$ 多糖合成酵素の予 測された2次構造が示してある。我々の解析ではNod Cのこの領 域は $\beta$ 多糖合成酵素ファミリーのメンバーの間で保存されてお り、上述したヌクレオチド結合B-モチーフと相同である。 ここで述べた $\beta$ 多糖合成酵素の保存されたエレメントの配 列はATP/GTP結合タンパク質においてもともと定義されたPloopやモチーフBの配列とは明らかに異なっている。このような 違いは驚くべきことではない。リン酸化酵素のファミリー内で さえも、P-loop配列中には顕著な違いがある。例えば、グリ七 ロールリン酸リン酸化酵素は、他のリン酸化酵素で見られる GXXXGK[T/S]ではなくGG[A/S ]KVXXKモチーフを含む(33、 $34)$ 。

結論的には、我々の結果はRossmannヌクレオチド結合 フォールドはヌクレオチド3リン酸結合タンパク質のみに存在す るのではなく、 $\beta$-多糖合成酵素ファミリーにも保存されている ことを示している。ここで述べた配列解析はヌクレオチド糖供 与体の結合におけるこれらのモチーフのさらなる研究を目的と した詳細な突然変異解析に理論的な基礎を提供するものであ る。

領域 3に類似のモチーフは $\beta$-多糖合成酵素だけでなく、ノ ンプロセッシブな $\beta$-糖転移酵素にも存在する $(3 、 39)$ 。Saxenaら (3)によって解析されたノンプロセッシブな転移酵素はマンノー ス-2リン酸ードリコールの合成に関与する糖転移酵素を含んでい るが、この酵素に使用される受容体は糖ではなくて脂質のドリ コールピロリン酸である。そのため、保存された領域 3 は受容体 との結合に関与するわけではなさそうである。おうらく、糖供 与体との相互作用に働いているのであろう。

領域 4 と領域 5 の機能に関する知見は $\beta$-多糖合成酵素のこ れらの領域のアミノ酸配列と $\beta-1-4-$ ガラクトース転移酵素 $(\beta-$ 


\begin{tabular}{|c|c|c|c|c|c|c|}
\hline region 1 & region 2 & region 3 & region 4 & region 5 & region 6 & \\
\hline \multirow{7}{*}{$K-\beta-D D G S$} & $R-\beta-G K R$ & hDSDT & GXXXXYR & GEDR $x \times T$ & QQXRW & $\beta$-polysaccharide \\
\hline & & A & $\mathrm{F}$ & $\begin{array}{l}\mathrm{SD} \\
\mathrm{T}\end{array}$ & $\mathrm{R}$ & $\begin{array}{l}\text { synthase } \\
\text { consensus }\end{array}$ \\
\hline & & FSDVDLIP & AIIIPYR & GEDDD & & $\beta$-GalT family \\
\hline & & $\mathrm{LH} \quad \mathrm{M}$ & $\mathrm{F}$ & A & & consensus \\
\hline & & & GXXXFYR & & & \\
\hline & & & $\mathrm{T} \quad \mathrm{K}$ & & & \\
\hline & & & $A$ & & & \\
\hline & ـ & L & ـ & L & لــ & \\
\hline UDP-binding & & $\begin{array}{r}\text { dor } \\
\text { saccharid }\end{array}$ & $\begin{array}{l}\text { or } \\
\text {-binding }\end{array}$ & $\begin{array}{c}\text { acceptor } \\
\text { saccharide- } \\
\text { binding }\end{array}$ & $\begin{array}{l}\text { product- } \\
\text { binding }\end{array}$ & $\begin{array}{l}\text { proposed } \\
\text { function }\end{array}$ \\
\hline
\end{tabular}

Fig. 5. Proposed functions of the six conserved regions in the $\beta$-polysaccharide synthase family. The consensus sequences in the $\beta$-galactosyl transferase family ( $\beta$-GalT) have been reported by (2). The label - $\beta$ - represents a predicted $\beta$ strand which is expected to be an element of a $\beta$-sheet. A black box is used to indicate the aspartic acid that is most likely to be the catalytic residue. Indications for the functional role of the conserved regions shown in this Figure are discussed in detail in the text.

acid sequences reported in the $\beta$-1-4-galactosyltransferase ( $\beta$ GalT) family (Fig. 5). Genes belonging to the $\beta$-GalT family have been grouped together based on their sequence similarities and the fact that all encode enzymes that transfer a single Galor GlcNAc-residue from a UDP-glycosyl donor to terminal $\beta$ linked GlcNAc residues in complex carbohydrates (2). Members of the $\beta$-GalT family contain several conserved sequences (2). One of these conserved sequences in the $\beta$-GalT family displays similarity with the conserved residues in the $\beta$-polysaccharide synthase region 3 , two $\beta$-GalT motifs resemble region 4 , and another motif in the $\beta$ GalT family members is similar to region 5 (Fig. 5). In the $\beta$-polysaccharide synthases, the presence of a Tyr in region 4 is correlated with specificity for GlcNAc (Fig. 2). In one of the two regions 4-like motifs conserved in GalTs and the GlcNAcT in the $\beta$-GalT family, we observed an identical correlation (Fig. 5). This region may therefore be involved in recognition of the saccharide in the donor-substrate. In contrast, the presence of a region 5-like sequence in both the GalTs and the GlcNAcT in the $\beta$-GalT family (2) (Fig. 5), clearly suggests that this region is involved in binding their common glycosyl acceptor: $\beta$-linked GlcNAc. Another indication that this region may directly interact with GlcNAc comes from the observation that the Gly in region 5 of the $\beta$-polysaccharide synthases is only conserved in transferases with a specificity for GlcNAc, whereas the Glc-specific enzymes contain a Ser or Thr at this position (Fig. 5). It is therefore tempting to speculate that the side chains of these Ser/Thr residues interact with the hydroxyl group on $\mathrm{C} 2$ of Glc. The presence of Gly, having the smallest side group of all amino acids, may then be required at
GalT)ファミリーで報告されている保存されたアミノ酸配列との 比較からもたらされる(図5)。 $\beta$-GalTファミリーに属する遺伝子 は、それらの配列の類似性とともに、それらすべてがUDP-糖供 与体からひとつのGal-またはGlcNAc-残基を複雑な炭水化物の末 端に $\beta$ 結合したGlcNAc残基に転移させる酵素をコードしている という事実によってグループ化された(2)。ß-GalTファミリーの メンバーはいくつかの保存された配列をもっている(2)。これら $\beta$-GalTファミリーで保存されている配列のうちの 1 つは $\beta-$ 多糖

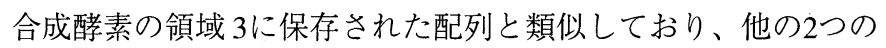
保存配列は領域 4 と似ており、さらにもう一つの保存配列は領 域5と類似している(図5)。 $\beta$-多糖合成酵素の領域4のTyrの存在 はGlcNAcに対する特異性と関係している(図2)。 $\beta$-GalTファミ リーのGalTとGlcNAcTに保存されている2つの領域4様モチーフ のうちの1つでは、同じ相関関倸が見られた(図5)。従って、この 領域は供与側の基質である糖の認識に関わっている可能性があ る。対照的に、 $\beta$-GalTファミリーにおけるGalTとGlcNAcT双方 に領域5様の配列が存在することは(2)(図5)、明らかにこの領域 がこれらの酵素に共通する糖受容体である $\beta$ 結合したGlcNAcと の結合に関与していることを示唆している。この領域が GlcNAc と直接相互作用しているだろうということを示すもう一つの証 拠は、 $\beta$-多糖合成酵素の領域 5 の Gly が GlcNAc 特異的な転移 酵素にのみ保存されているのに対して、Glc特異的な酵素はこの 位置に Serか Thr がくるということである(図5)。つまり、これ らのSer/Thr 残基の側鎖が Glc の C2の水酸基と相互作用すると 推測できる。すべてのアミノ酸のなかで最も小さい側鎖をもつ 
this position to allow docking of the $\mathrm{N}$-acetyl group of GlcNAc. The presence of region 4- and 5-like sequences in the nonprocessive $\beta$-GalTs shows that these regions can no longer be regarded as unique for processive $\beta$-glycosyltransferases. It has therefore become doubtful whether these regions are part of the processivity-domain as was proposed by Saxena and co-workers (3).

\section{C-4. Control of Product Chain Length}

Functional analysis of chimeric nodC genes derived from the M.loti "chitinpentaose synthase" and the S.meliloti "chitintetraose synthase" indicates that the predominant production of chitintetraose by S.meliloti NodC is determined by a combination of an $\mathrm{N}$-terminal region of maximally 170 amino acids, and the C-terminal 164 residues (E.Kamst et al., submitted). Exchange of the C-terminal domains alone, however, is sufficient to convert the M.loti "chitinpentaose synthase" into an S. meliloti -like "chitintetraose synthase". There is a relationship between the length of a predicted $\beta$-strand in the C-terminus of NodC, and the relative amount of chitintetraose produced: the predicted strand is shorter in those NodC proteins that predominantly synthesize chitintetraose. This $\beta$-strand element may therefore be responsible for the effect of the C-terminal 164 amino acids on chitin oligosaccharide chain length described above. The well-conserved QXXRW sequence (Fig. 5, region $6)$ that is located close to the $\beta$-strand element discussed above, has only been described in processive $\beta$-glycosyltransferases, and is not detected in several related nonprocessive glycosyltransferases (3) (E.Kamst, unpublished results), suggesting that it is part of the processivity-domain.

A model combining these conclusions as to the possible roles of the conserved protein motifs in processive $\beta$ glycosyltransferases is shown in Fig. 5. It should be noted that the proposed functions are at present still speculative, since there are no experimental data available on the involvement of the six conserved regions in substrate binding and catalysis. However, the recent development of a glycosyltransferase assay for NodC using an artificial acceptor (17) is expected to allow the demonstration of enzyme activity regardless whether the processive nature of NodC is intact or not, allowing mutational identification of domains involved in processivity. In addition, acceptors containing saccharides other than GlcNAc can be tested for their ability to act as substrates. These are the tools that will enable a detailed analysis of substrate specificity, monosaccharide donor binding, acceptor binding, and processivity of NodC, leading to a better understanding of the structure-function relationships in $\beta$-polysaccharide synthases in general.
Glyが存在することが、この領域がGlcNAcのN-アセチル基と合 体するのに必要であるのかもしれない。ノンプロセッシブな $\beta$ GalTに領域 4および 5 様の配列が存在することは、これらの領 域がプロセッシブな $\beta$-糖転移酵素に特有のものではないという ことを示している。そのため、これらの領域がプロセッシビ ティードメインの一部であるという、Sexena と共同研究者たち の提案した説(3)は疑わしくなった。

\section{C-4. 生成糖鎖長の制御}

M.loti「キチンペントース合成酵素」とS.meliloti「キチンテ トラオース合成酵素」由来のキメリックな Nod C 遺伝子の機能 解析の結果は、S. meliloti Nod Cの主要な生成物であるキチンテ トラオースの生成は、最大 170 アミノ酸の $\mathrm{N}$ 末端領域と C 末端 領域164残基の組み合わせによって決定されているということを 示している(E. Kamstら、投稿中)。しかし、C末端側のドメイン のみ交換しても、M. lotiの「キチンペントース合成酵素」を S.meliloti様の「キチンテトラオース合成酵素」に変換するには 十分である。 Nod CのC末端の $\beta$ 鎖の長さと生成されるキチンテ トラオースの相対的な量の間には関係がある。主にキチンテト ラオースを合成するNodCタンパクに扔いては、この $\beta$ 鎖は(キ チンペントースを合成するものに比べて)短かった。従って、こ の $\beta$ 鎖部分が、上述したキチンオリゴ糖鎖長に対するC末端164 アミノ酸の効果の原因であると考えられる。この $\beta$ 鎖部分の近 傍に位置するよく保存されたQXXRW配列(図5、領域6)は、プロ セッシブな $\beta$-糖転移酵素にのみ見られ、いくつかの近縁のノン プロセッシブな糖転移酵素では見られない(3)(E. Kamst，未発表 結果)。このことは、それがプロセッシビテイドメインの一部で あることを示唆している。

プロセッシブな $\beta$-糖転移酵素で保存されているタンパク質 モチーフの可能な役割に関するこのような結論をあわせたモデ ルを図5に示した。注意すべきは、提案した機能は現時点では 未だ推測の域を出ていないということである。基質結合性や触 媒作用に対する6つの保存された領域の関与に関して利用可能な 実験デー夕はない。しかし、最近の人工受容体を利用したNodC の糖転移酵素アッセイ法の開発(17)により、NodCのプロセッシ ブな性質がそこなわれているといないとに関わりなく酵素活性 を調べることが可能になったので、突然変異を利用したプロ セッシビティに関するドメインの同定ができるものと期待され る。さらに、GlcNAc以外の糖を含む受容体も基質として働くか どうかをテストすることも可能である。これらにより、基質特 異性、単糖供与体結合性、受容体結合性拈よびNod Cのプロセッ シビティの詳細な解析が可能となり、一般的な $\beta$-多糖合成酵素 における構造と機能の関係がよりよく理解されるようになるで あろう。

農林水産省 生物資源研究所

梅原 洋佐 訳 


\section{References}

1. Datta, A.K., and Paulson, J.C. (1997) Indian J. Biochem. Biophys. 34, 157-165

2. van Die, I., Bakker, H., and van den Eijnden, D.H. (1997) Glycobiology 7, v-ix

3. Saxena, I.M., Brown jr, R.M., Fevre, M., Geremia, R.A., and Henrissat, B. (1995) J. Bacteriol. 177, 1419-1424

4. Bulawa, C.E., and Wasco, W. (1991) Nature (London) 353, 710

5. Atkinson, E.M., and Long, S.R. (1992) Mol. Plant-Microbe Interact. 5, 439-442

6. Debell , F., Rosenberg, C., and Dènariè, J. (1992) Mol. Plant-Microbe Interact. 5, 443-446

7. Cohen, E. (1987) Ann. Rev. Entomol. 32, 71-93

8. Kamst, E., Spaink, H.P., and Kafetzopoulos, D. (1998) in Plant-Microbe Interactions (Biswas, B.B., and Das, H.K., eds.) pp. 29-71, Plenum Press, New York

9. Spaink, H.P., Sheeley, D.M., van Brussel, A.A.N., Glushka, J.N., York, W.S., Tak, T., Geiger, O., Kennedy, E.P., Reinhold, V.N., and Lugtenberg, B.J.J. (1991) Nature (London) 354, 125-130

10. Kamst, E., van der Drift, K.M.G.M., Thomas-Oates, J.E., Lugtenberg, B.J.J., and Spaink, H.P. (1995) J. Bacteriol. 177, $6282-6285$

11. Mergaert, P., D’Haeze, W., Geelen, D., Prom , D., van Montagu, M., Geremia, R.A., Prom , J.C., and Holsters, M. (1995) J. Biol. Chem. 270, 29217-29223

12. Bugg, T.D.H., and Brandish, P.E. (1994) FEMS Microbiol. Lett. 119, 255-262

13. Lavintman, N., and Cardini, C.E. (1973) FEBS Lett. 29, 43-46

14. Bocca, S.N., Rothschild, A., and Tandecarz, J.S. (1997) Plant Physiol. Biochem. 35, 205-212

15. Pitcher, J., Smythe, C., and Cohen, P. (1988) Eur. J. Biochem. 176, 391-395

16. Lomako, J., Lomako, W.M., and Whelan, W.J. (1988) Federation of American Soc. for Exp. Biol. J. 2, 3097-3103

17. Kamst, E., Bakkers, J., Quaedvlieg, N.E.M., Kijne, J.W., Lugtenberg, B.J.J., and Spaink, H.P. (1999) Biochemistry 38, 4045-4052

18. Lehle, L., and Tanner, W. (1976) FEBS Lett. 71, 167-170

19. Varki, A. (1996) Proc. Natl. Acad. Sci. USA 93, 4523-4525

20. Semino, C.E., and Robbins, P.W. (1995) Proc. Natl. Acad. Sci. USA 92, 3498-3501

21. Semino, C.E., Specht, C.A., Raimondi, A., and Robbins, P.W. (1996) Proc. Natl. Acad. Sci. USA 93, 4548-4553

22. Bakkers, J., Semino, C.E., Stroband, H., Kijne, J.W., Robbins, P.W., and Spaink, H.P. (1997) Proc. Natl. Acad. Sci. USA 94, $7982-7986$

23. DeAngelis, P. L., and Achyutan, A.M. (1996) J. Biol. Chem. 271, 23657-23660

24. Meyer, M.F., and Kreil, G. (1996) Proc. Natl. Acad. Sci. USA 93, 4543-4547

25. Prehm, P. (1983) Biochem. J. 211, 191-198

26. Kamst, E., Pilling, J., Raamsdonk, L.M., Lugtenberg, B.J.J., and Spaink, H.P. (1997) J. Bacteriol. 179, 2103-2108

27. Albersheim, P., Darvill, A., Roberts, K., Staehelin, L.A., and Varner, J.E. (1997) Plant Physiol. 113, 1-3

28. Freemont, P.S., Friedman, J.M., Beese, L.S., Sanderson, M.R., and Steitz, T.A. (1988) Proc. Natl. Acad. Sci. USA 85, $8924-8928$

29. Vrielink, A., R ger, W., Driessen, H.P.C., and Freemont, P.S. (1994) EMBO J. 13, 3413-3422

30. Josse, J., and Kornberg, A. (1962) J. Biol. Chem. 237, 1968-1976

31. Rossmann, M. G., Liljas, A., Branden, C.I., and Babaszak, L.J. (1975) in Anonymouspp. pp. 62-103, Academic Press, NY/London

32. Walker, J.E., Saraste, M., Runswick, M.J., and Gay, N.J. (1982) EMBO J. 1, 945-951

33. Saraste, M., Sibbald, P.R., and Wittinghofer, A. (1990) TIBS 15, 430-434

34. Smith, C.A., and Rayment, I. (1996) Biophys. J. 70, 1590-1602

35. Pai, E.F., Krengel, U., Petsko, A., Goody, R.S., Kabsch, W., and Wittinghofer, A. (1990) EMBO J. 9, 2351-2359

36. Noel, J.P., Hamm, H.E., and Sigler, P.B. (1993) Nature (London) 366, 654-663

37. Kjeldgaard, M., Nissen, P., Thirup, S., and Nyborg, J. (1993) Structure 1, 35-50

38. Kamst, E., Lugtenberg, B.J.J., and Spaink, H.P. (1996) in Chitin Enzymology (Muzzarelli, R.A.A. ed.) pp. 329-338, Atec Edizioni, Italy

39. Wiggins, C.A.R., and Munro, S. (1998) Proc. Natl. Acad. Sci. USA 95, 7945-7950

40. Rossen, L., Johnston, A.W.B., and Downie, J.A. (1984) Nucl. Acids Res. 12, 9497-9508

41. Valdivieso, M.H., Mol, P.C., Shaw, J.A., Cabib, E., and Duran, A. (1991) J. Cell. Biol. 114, 101-109

42. Rosa, F., Sargent, T.D., Rebbert, M. L., Michaels, G.S., Jamrich, M., Grunz, H., Jonas, E., Winkles, J.A., and Dawid, I.B. (1988) Develop. Biol. 129, 114-123

43. DeAngelis, P.L., Papaconstantinou, J., and Weigel, P.H. (1993) J. Biol. Chem. 268, 19181-19184

44. Matthysse, A.G., Thomas, D.L., and White, A.R. (1995) J. Bacteriol. 177, 1076-1081

45. Dillard, J.P., Vandersea, M.W., and Yother, J. (1995) J. Exp. Med. 181, 973-983

46. Sinnott, M.L. (1990) Chem. Rev. 90, 1171-1202

47. Gibrat, J.F., Garnier, J., and Robson, B. (1987) J. Mol. Biol. 198, 425-443

48. Levin, J.M., Robson, B., and Garnier, J. (1986) FEBS Lett. 205, 303-308

49. Deleage, G., and Roux, B. (1987) Protein Eng. 1, 289-294

50. Geourjon, C., and Deleage, G. (1995) Comput. Appl. Biosci. 11, 681-684

51. Rost, B., and Sander, C. (1994) Proteins 19, 55-72

52. Kneller, D.G., Cohen, F.E., and Langridge, R. (1990) J. Mol. Biol. 214, 171-182

53. Arioli, T., Peng, L.C., Betzner, A.S., Burn, J., Wittke, W., Herth, W., Camilleri, C., Hofte, H., Plazinski, J., Birch, R., Cork, A., Glover, J., Redmond, J., and Williamson, R.E. (1998) Science 279, 717-720

(Received on May 6, 1999, accepted on May 13, 1999) 


\section{Profile of Authors}

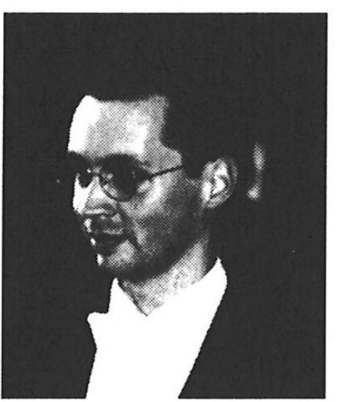

Eric Kamst is a molecular biologist, who graduated in Biology at Leiden University, The Netherlands in 1994. During his study he was involved in research on multidrug resistance in lung-tumor cells at the Netherlands Cancer Institute in Amsterdam, and the biosynthesis of mitogenic lipochitin oligosaccharides by Rhizobium bacteria at the Institute of Molecular Plants Sciences, Leiden University. After graduating, he continued studying the biosynthesis of lipochitin oligosaccharides, this time focusing on the oligoasccharide formation and obtained his PhD in april 1999. Presently, he holds a position at DSM Anti-Infectives, located at Delft, The Netherlands. where he studies penicillin biosynthesis in fungi.

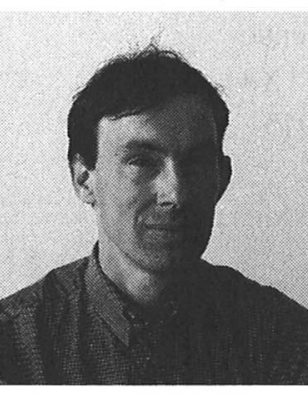

Herman P. Spaink is a Professor in Molecular Cell Biology at Leiden University. He gained his Ph.D. at Leiden University (The Netherlands) in 1989 on a study of the Rhizobium-plant interaction. After his Ph.D. he has had postdoctoral positions at Harvard Medical School (Boston)and briefly at the Australian National University (Canberra). After that he returned to Leiden University in 1990 where he is currently head of the Department of Molecular Cell Biology in the Institute of Molecular Plant Sciences. His research interest are the signal transduction of chitin oligosaccharides and their role in organogenesis in plants and animals. His major expertise is in molecular biology, with emphasis on glycobiology and cell biology. 